ressembler une éthique plus large que celle restreinte de nos travaux d'aujourd'hui. «Plutôt que défendre la lettre des articles des droits de l'homme, comme le ferait un juriste procédurier, il faut s'attacher au sens central de ces droits, c'est-à-dire une notion d'égale dignité de et pour tous.»

S'agissant d'éthique globale, avec pour objet et souci la planète et ses habitants, nous sommes démunis. C'est aussi ce que dit E. Taverna citant Hans Jonas. Comment avancer mieux? Formaliser et mettre en oeuvre des droits de la collectivité? Mais, même si c'est indispensable, les difficultés sont sérieuses pour définir l'intérêt général. Et qui donne attention aux intérêts des générations futures - eux aussi difficiles à préciser, relèvent nos critiques! Il reste que l'accent mis sur des droits individuels toujours plus nombreux (œdématiés!) doit être revu dans un sens solidaire et prospectif.

Promouvoir un changement de conscience et de pratiques, en particulier de nous les nantis et gaspilleurs-pollueurs, programme indispensable. Mais les obstacles sont formidables par la mise au défi du système démocratique où chacun vote pour l'essentiel selon son intérêt propre à court terme. Pas simple de mettre en œuvre une "éducation à la survie» au plan mondial! Pourtant, sous peine de fin d'histoire il faudra trouver les voies et moyens d'une nouvelle éthique, englobante, planétaire.

Dr Jean Martin, Echandens

1 Taverna E. La technique et ses conséquences. Bull Méd Suisses. 2015; 96(20-21):754.

2 Hunyadi M. La tyrannie des modes de vie. Lormont: Ed. Le Bord de l'Eau; 2015.

\section{Generationenkonflikt in der} Hausarztmedizin

\section{Zum Brief von René Bloch [1]}

Dem Leserbrief von Herrn Dr. René Bloch [1] kann ich als alter Hausarzt nur beipflichten. In der klinischen Ausbildung hat es uns immer wieder imponiert, wie mit Hilfe der Stethoskopie und Perkussion schnell, einfach und billig Befunde oder sogar Diagnosen von Herz, Lunge oder Bauch gestellt werden konnten. Chefärzte und Oberärzte haben uns dies beigebracht und auch unsere Aussagen kontrolliert. Es brauchte einige Zeit, bis man etwas Erfahrung darin hatte. Ich erinnere mich an einen Spitaleintritt, wo ich auskultatorisch eine Pneumonie vermutete, das Infiltrat aber im Thoraxbild noch nicht abgebildet war. Die Auskultation kann also auch mal schneller als das Thoraxröntgen sein! Immer wieder höre ich, wie bei einem Spitaleintritt Herz und Lungen kaum oder überhaupt nicht abgehört werden. Der Patient wird einfach ins Röntgen geschickt. Das ist ja einfacher. Wie sollen dann die jungen Hausärzte auf ihren Visiten Befunde oder Diagnosen ohne Röntgen erstellen können?

Überhaupt gibt der normale Status einen Kontakt zum Patienten, der durch die raffiniertesten Techniken nicht zu ersetzen ist. Auf die Anamnese hat man einen grossen Wert gelegt, und in komplizierten Fällen wurde grafisch ein Zeitraster der Ereignisse erstellt, der eine bessere Übersicht und neue Zusammenhänge lieferte. Zum Schluss möchte ich fragen, warum in den Kliniken Chefärzte und Oberärzte kein Gewicht oder nur ungenügend auf diese einfachen Methoden legen. Es wäre ihre Aufgabe im eigentlichsten Sinn!

Dr. med. Roland Scholer, Liestal

1 Bloch R. Generationenkonflikt in der Hausarztmedizin. Schweiz Ärztezeitung. 2015;96(12):427.

\section{Inakzeptable Vorschriften}

In unserem Einkaufszentrum erstellte mir in der Amplifon-Filiale die Akusterin Frau Suter ein Audiogramm und programmierte ein Hörgerät, Kosten CHF 4214.50. Die AHV würde einen Zuschuss von CHF 800.- leisten; allerdings nur unter der Bedingung einer nachträglichen Konsultation bei einem ORL-Spezialisten.

Dies ist meines Erachtens eine Art Erpressung, vor allem aber diskriminiert dies alle Hausärzte und erhöht unnötigerweise die Gesundheitskosten.

Ich kann solche Vorschriften nicht akzeptieren und verzichte auf die CHF 800.-

Dr. med. Rudolf Aschbacher, Bolligen

\title{
Mitteilungen
}

Facharztprüfungen

Korrigendum

(ersetzt die Ausschreibung vom 13.5.2015)

Facharztprüfung zur Erlangung des

Schwerpunktes für Hals- und Gesichtschirurgie zum Facharzttitel ORL

Ort: Wird individuell mit dem Kandidaten abgemacht.

Datum: Wird individuell mit dem Kandidaten abgemacht.

Anmeldefrist: Eine Anmeldung ist das ganze Jahr möglich.
Weitere Informationen finden Sie auf der Website des SIWF unter www.siwf.ch $\rightarrow$ Fachgebiete $\rightarrow$ Facharzttitel und Schwerpunkte (Weiterbildung) $\rightarrow$ Hals- und Gesichtschirurgie zum Facharzttitel ORL

Facharztprüfung zur Erlangung des Schwerpunktes Pädiatrische Endokrinologie-Diabetologie zum Facharzttitel für Kinder- und Jugendmedizin

Ort: Universitäts-Kinderspital Genf (HUG), 6, rue Willy Donzé, 1211 Genf

Datum: Donnerstag, 19. November 2015
Zeit: 8.00 Uhr-12.00 Uhr mündliche Prüfung (1 Stunde pro Kandidat), 13.30 Uhr-16.00 Uhr schriftliche Prüfung (auf Englisch)

\section{Anmeldefrist: 15. August 2015}

Weitere Informationen finden Sie auf der Website des SIWF unter www.siwf.ch $\rightarrow$ Fachgebiete $\rightarrow$ Facharzttitel und Schwerpunkte (Weiterbildung) $\rightarrow$ Kinder- und Jugendmedizin 
Swiss Society for Hospital Hygiene (SSHH) / Swiss Society for Infectious Diseases (SSI)

\section{Awards 2015}

The Swiss Society for Hospital Hygiene (SSHH), the Swiss Society for Infectious Diseases (SSI) and the Swiss Academic Foundation for Education in Infectious Diseases (SAFE-ID) will award 3 prizes each in the amount of $15000 \mathrm{CHF}$ for outstanding scientific achievements in basic research in infectious diseases, clinical research in infectious diseases and research in infection control / hospital epidemiology during the 2015 joint annual meeting.

Eligibility: Authors of an outstanding scientific publication in basic, clinical or epidemiological research in infectious diseases. A significant part of the work must have been performed in Switzerland. The paper (or group of related papers) must have been either published or accepted for publication by an internationally renowned peer-reviewed journal between July 1st 2014 and July 15th 2015.

Conditions: Applications should be accompanied by a cover letter including the name and e-mail address of the applicant and the prize category applied for. If the paper is accepted but not yet published, please attach the letter of acceptance. The applicant must be an active member of the Swiss Society for Hospital Hygiene (SSHH) and/or the Swiss Society for Infectious Diseases (SSI). All authors agree with the application. A prize committee designated by the committee of the SSI and SSHH performs the evaluation. Decisions made by the committee are definitive and not subject to appeals. The award is intended to support a research project of the awardee. The award is given to applicant in person at the 2015 joint annual conference of the Swiss
Society of Intensive Care Medicine (SGI-SSMI), Swiss Society for Infectious Diseases (SSI), Swiss Society of Emergency Medicine (SGNOR/ SSMUS) and Swiss Society for Hospital Hygiene (SSHH) that will be held from September 2 to 4, 2015 at the Congress Centre Kursaal Interlaken. The awardee is expected to give a short presentation of the work during the award ceremony on Thursday, September 3rd, 2015. The award is publicized in the Swiss medical press, on the SSI the SSHH and the SAFE-ID websites and to the members of the SSI and SSHH.

\section{Deadline for applications: July 1st, 2015.}

Please submit the documents by e-mail to the president of the prize committee: Prof. Dr. med. Stephen Leib, Universität Bern, Institut für Infektionskrankheiten, Friedbühlstrasse 51, 3010 Bern, Switzerland, e-mail: stephen.leib[at]ifik.unibe.ch.

\section{Aktuelle Forumthemen}

Jetzt online mitdiskutieren auf www.saez.ch

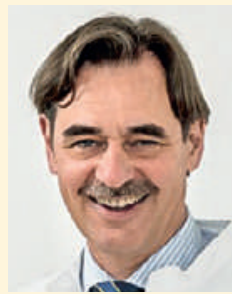

Dr. med. Josef E. Brandenberg, Luzern

\section{Spezialuntersuchungen}

Braucht es immer ein MRI?

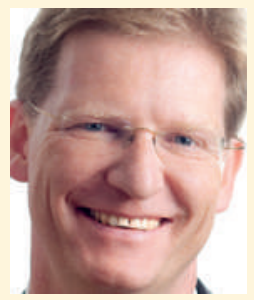

Dr. med. Michael Stamm, D.E.A.A.,

Facharzt für Anästhesiologie und Intensivmedizin, EMBA Universität Zürich

Medizinischer Leiter und Geschäftsführer der Operationszentrum Burgdorf AG

Ambulante Leistungen

Förderung ambulanter Leistungen als Antwort auf Herausforderungen im Schweizer Gesundheitswesen 